\title{
Pembungaan dan Pembentukan Benih \\ pada Beberapa Genotipe Kubis Bunga (Brassica oleracea var. botrytis L.)
}

\section{Flowering and Seeds Formation of Several Genotypes Cauliflower (Brassica oleracea var. botrytis L.)}

\author{
Dyra Haryanti ${ }^{1}$, Darda Efendi ${ }^{2,3^{*}}$, Sobir ${ }^{2,3}$ \\ ${ }^{1}$ Program Studi Pemuliaan dan Bioteknologi Tanaman, Sekolah Pasca sarjana, Departemen Agronomi dan Hortikultura, \\ Fakultas Pertanian Institut Pertanian Bogor, Bogor, Indonesia \\ ${ }^{2}$ Departemen Agronomi dan Hortikultura, Fakultas Pertanian Institut Pertanian Bogor \\ Jl. Meranti Kampus IPB Darmaga, Bogor, Indonesia \\ ${ }^{3}$ Pusat Kajian Hortikultura Tropika (PKHT) Institut Pertanian Bogor, Kampus IPB Baranangsiang \\ Jl. Raya Pajajaran Bogor, Indonesia
}

Diterima 8 Februari 2019/Disetujui 22 Februari 2019

\begin{abstract}
Seed is the most important part of plants in the breeding of plants, especially plants that are generatively propagated. Cauliflower come from the subtropical region that is bred with seeds. Low temperatures are needed by plants to produce curd and flowers. Research were held at Pasir Sarongge, Cianjur (1,117 m asl) from June to November 2016 and Tajur II, Bogor (340 m asl) from July to December 2016, while seed testing at PKHT Laboratory, IPB in October 2017. This research used randomized complete block design single-factor with three replications. The formation of seeds is only produced in plants that planted in the high elevation. Genotypes BOB 001, BOB 002, BOB 003, and BOB 013 have germinationover 80\% and high viability. Early flowering time can be seen from the early of time forming curd, time of forming compact curd, time of seed harvesting, and increasing weight of 1,000 seeds.
\end{abstract}

Keywords: flowering, low temperature, viability

\section{ABSTRAK}

Benih merupakan bagian terpenting tanaman dalam perkembangbiakan tanaman, terutama tanaman yang perbanyakannya secara generatif. Kubis bungaberasal dari wilayah subtropis yang dikembangbiakan dengan benih. Suhu rendah dibutuhkan tanaman untuk menghasilkan curd dan bunga. Penelitian dilaksanakan di Kebun Percobaan Pasir Sarongge, Cianjur (1,117 m dpl) pada Juni sampai November 2016 dan Kebun Percobaan Tajur II, Bogor (340m dpl) pada Juli sampai Desember 2016, sedangkan pengujian benih Laboratorium PKHT, IPB pada bulan Oktober 2017. Rancangan yang digunakan adalah rancangan kelompok lengkap teracak faktor tunggal dengan tiga ulangan.Benih hanya dihasilkan pada tanaman yang ditanam di dataran tinggi. Genotipe BOB 001, BOB 002, BOB 003, dan BOB 013 memiliki daya berkecambah diatas $80 \%$ dan memiliki vabilitas yang tinggi. Waktu berbunga yang cepat dapat dilihat dari cepatnya waktu membentuk curd, waktu curd kompak, waktu waktu panen benih, dan meningkatnya bobot 1,000 benih.

Kata kunci :pembungaan, suhu rendah, viabilitas

\section{PENDAHULUAN}

Kubis bunga (Brassica oleracea var. botrytis L.) merupakan sayuran yang mengandung antioksidan, vitamin A, vitamin B-6, vitamin E, dan memiliki kandungan fitokimia seperti glucoraphanin, sulforaphane (SNF), glucobrassicin, indole-3-carbinole (I3C), dan ascorbigen (ABG) yang bermanfaat sebagai penawar racun dalam tubuh, anti inflamasi, anti ulcerogenik, anti hiperglikemia, dan anti

\footnotetext{
* Penulis untuk korespondensi. e-mail: dardaefendi@gmail. com
}

kanker (Kim 2014). Gray (1982) menyatakan bahwa kubis bunga kemungkinan berasal dari brokoli karena berdasarkan fakta bahwa bentuknya yang sangat khusus. Kepala bunga pada kubis bunga disebut curd, yaitu merupakan sekelompok kuncup bunga padat yang tidak sepenuhnya berkembang yang terbentuk oleh gagalnya pembentukan meristem pembungaan (Gray, 1982) dan merupakan fase layak panen atau konsumsi. Curd akan membentuk bunga dan menghasilkan benih. Benih merupakan bagian terpenting tanaman dalam perkembangbiakan tanaman, terutama tanaman kubis bunga yang diperbanyak secara generatif.

Kubis bunga berasal dari wilayah subtropik, yaitu Mediterania (Arias et al., 2014). Suhu merupakan faktor penting untuk penentuan kemampuan beradaptasi tanaman 
subtropis di wilayah tropis. Peningkatan suhu (global warming) merupakan salah satu masalah yang penting saat ini. Suhu tinggi merupakan masalah utama pada tanaman subtropis yang ditanam di wilayah tropis. Driedonks et al. (2016) menyatakan bahwa sensitivitas terhadap suhu tinggi bervariasi antara jenis tanaman, spesies dan kultivar. Suhu rendah dibutuhkan tanaman kubis bunga untuk menghasilkan curd dan bunga. Guo et al. (2004) menyatakan bahwa suhu rendah sangat penting untuk menghasilkan bunga, tetapi tidak untuk pembentukan curd pada beberapa varietas kubis bunga. Penelitian mengenai pengaruh suhu terhadap pembentukan curd telah dilakukan, diantaranya Gomies et al. (2012), Matschegewski et al. (2015), dan Hasan et al. (2016), tetapi penelitian terkait pembentukan benih pada kubis bunga masih kurang. Penelitian ini bertujuan untuk mengidentifikasi pengaruh perbedan lokasi penanaman, yaitu dataran tinggi dan dataran rendah terhadap pembentukan benih beberapa genotipe kubis bunga.

\section{BAHAN DAN METODE}

Penelitian terbagi menjadi dua percobaan, diantaranya percobaan pertama yaitu pembenihan kubis bunga di dua lokasi dan pengujian benih kubis bunga. Percobaan pertama dilaksanakan di Kebun Percobaan Pasir Sarongge, Cianjur 1,117 m dpl/dataran tinggi pada bulan Juni sampai November 2016 dan Kebun Percobaan Tajur II, Bogor 340 $\mathrm{m}$ dpl/dataran rendah pada bulan Juli sampai Desember 2016. Pengujian dilaksanakan di Laboratorium Pusat Kajian Hortikultura Tropika (PKHT) IPB, Bogor pada bulan Oktober 2017. Kondisi lingkungan selama percobaan pengujian benih memiliki suhu berkisar $24.5-26.7{ }^{\circ} \mathrm{C}$ dan kelembaban berkisar 54-67\%. Materi genetik yang digunakan adalah lima genotipe kubis bunga koleksi PKHT IPB, yaitu BOB 001, BOB 002, BOB 003, BOB 013, dan BOB 014. Rancangan yang digunakan adalah rancangan kelompok lengkap teracak (RKLT) dengan tiga ulangan. Percobaan pertama terdiri atas lima tanaman per ulangan, sedangkan percobaan kedua terdiri atas 25 benih per ulangan.

Tanaman ditanam pada kedua lokasi penelitian dengan melakukan prosedur tahapan budidaya petani kubis bunga pada umum dengan jarak tanam rekomendasi Hossain et al. (2011) yaitu $60 \mathrm{~cm} \mathrm{x} 40 \mathrm{~cm}$. Pembenihan dilakukan dengan cara pembenihan alami. Tanaman dibiarkan tumbuh di lahan hingga melewati masa panen (over ripening) sampai menghasilkan benih. Individu tanaman yang dibenihkan dilakukan penyungkupan pada sore hari dan dilepas sungkupnya pada pagi hari. Hal ini dilakukan setiap hari sejak tanaman telah membentuk curd hingga cabang curd memanjang membentuk kuncup bunga. Benih kubis bunga dipanen saat kapsul benih sudah kering. Kapsul benih yang baru dipanen dikeringkan dengan cara dijemur dengan sinar matahari langsung, setelah kering perentelan benih dari kapsulnya dilakukan. Benih yang telah bersih dimasukkan ke dalam kemasan plastik polietilen, yaitu satu plastik per tanaman per panen. Selanjutnya benih disimpan di kulkas (suhu $1-40{ }^{\circ} \mathrm{C}$ dan $\mathrm{RH} 49-69 \%$ ) selama \pm 12 bulan. Pengamatan uji daya berkecambah benih dilakukan pada hari ke- 5 dan 10. Benih diberi perlakuan dengan dilakukan perendaman pada suhu $55{ }^{\circ} \mathrm{C}$ selama satu jam, sebelum dilakukan pengujian benih. Pengujian dilakukan dengan metode Uji Diatas Kertas (UDK). Benih dikecambahkan diatas tiga lembar kertas buram yang telah dilembabkan di atas cawan petri. Penyiraman media kertas buram dilakukan setiap hari untuk mempertahankan kelembaban.

Pengamatan karakter kuantitatif terdiri atas diameter curd, waktu membentuk curd, waktu curd kompak, waktu berbunga, waktu panen benih,jumlah benih per curd, jumlah benih per polong, bobot 1,000 benih, daya berkecambah pada 5 hari setelah perlakuan (HSP), dan 10 HSP. Karakter kualitatif yang diamati terkait pembenihan, yaitu warna antosianin pada curd setelah masak panen, warna bunga, perilaku kapsul benih, permukaan kapsul benih, bulu pada kapsul benih, dan warna utama kapsul benih setelah kering. Analisis data yang digunakan pada kedua percobaan ini adalah analisis menggunakan uji F, jika perlakuan berpengaruh nyata maka dilakukan uji lanjut menggunakan duncan multiple range test (DMRT) pada taraf 5\%; dan analisis korelasi dengan metode Pearson, untuk mengetahui adanya hubungan antarkarakter yang diamati. Perangkat lunak yang digunakan, yaitu STAR versi 2.0.1.

\section{HASIL DAN PEMBAHASAN}

\section{Pengaruh Suhu terhadap Pembenihan}

Penelitian menunjukkan bahwa pembenihan hanya berhasil di dataran tinggi. Lima genotipe yang dujikan berhasil menghasilkan benih di dataran tinggi, yaitu BOB 001, BOB 002, BOB 003, BOB 013, dan BOB 014. Proses pembenihan pada kubis bunga dapat dilihat pada Gambar 1. Pada lokasi dataran rendah, tanaman hanya mengalami tahap pertama dalam proses pembenihan, yaitu curd tidak beraturan dan pemanjangan cabang bunga. Rihan et al. (2017) menyatakan bahwa pembentukan benih secara alami mencakup proses fertilisasi pada ovul sampai benih masak dipengaruhi oleh genetik.

Suhu rata-rata per bulan selama penelitian di dua lokasi selama penelitian, yaitu kisaran $21.00-23.50{ }^{\circ} \mathrm{C}$ di dataran tinggi dan $26.00-26.20^{\circ} \mathrm{C}$ di dataran rendah (BMKG 2017). Berdasarkan penelitian Guo et al. (2004), tanaman yang ditanam pada suhu $25{ }^{\circ} \mathrm{C}$ tidak dapat berbunga meskipun telah diberi perlakuan giberelin (GA). Penanaman di dataran tinggi memiliki kondisi lingkungan yang sesuai dan suhu rendah yang selalu tesedia, sehinggatanaman yang memiliki kondisi sesuai dapat berbunga dan menghasilkan benih. Genotipe BOB 001, BOB 002, BOB 003, BOB 013, dan BOB 014 mampu menghasikan benih pada suhu kisaran 21.00-23.50 ${ }^{\circ} \mathrm{C}$. Penelitian ini menunjukkan bahwa kubis bunga sudah tidak dapat berbunga dan menghasilkan benih pada suhu kisaran $26^{\circ} \mathrm{C}$.

\section{Karakter Pembentukan Benih}

Karakter kualitatif yang diamati pada masa pembenihan kubis bunga, yaitu warna antosianin pada 
curd setelah masak panen, warna bunga, perilaku kapsul benih, permukaan kapsul benih, bulu pada kapsul benih, warna utama kapsul benih setelah kering. Hasil pengamatan menunjukkan bahwa lima genotipe di dataran tinggi yang diamati (BOB 001, BOB 002, BOB 003, BOB 013, dan BOB 014) menunjukkan kesamaan pada enam karakter kualitatif yang diamati. Kelima genotipe memiliki warna antosianin pada curd setelah masak, warna bunga kuning, perilaku kapsul tegak, permukaan kapsul bergelombang, tidak ada bulu pada kapsul benih, dan warna utama kapsul benih setelah kering adalah coklat terang. Tanaman di dataran rendah hanya mengalami tahap pertama dalam proses pembenihan (curd tidak beraturan dan pemanjangan cabang bunga) hanya dapat diamati karakter antosianin pada curd. Hasil penelitian menunjukkan kelima genotipe tidak memiliki warna antosianin pada curd setelah masak panen. Hal ini dapat mengindikasikan bahwa suhu rendah kemungkinan memiliki pengaruh terhadap kandungan antosianin pada curd kubis bunga.

Pengamatan kuantitatif karakter pembentukan benih pada percobaan satu terdiri atas waktu membentuk curd, waktu curd kompak, waktu berbunga, waktu panen benih, dan diameter curd. Karakter waktu membentuk curd, waktu curd kompak, waktu berbunga, dan waktu panen benih ditunjukkan pada Tabel 1. Genotipe BOB 013 nyata lebih tinggi berdasarkan karakter waktu membentuk curd, waktu curd kompak, waktu berbunga, dan waktu panen benih
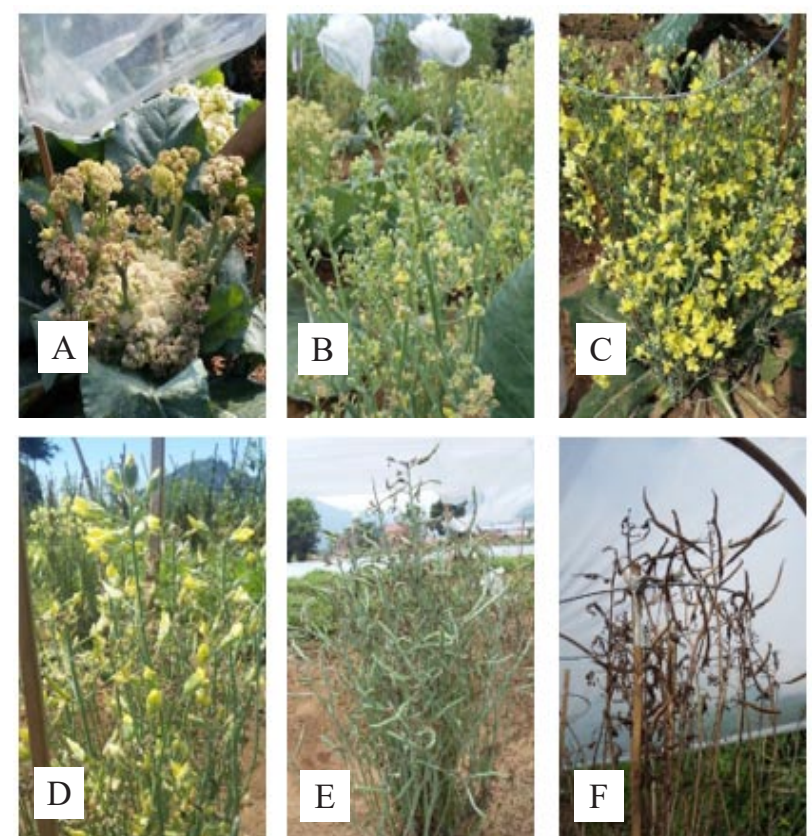

Gambar 1. Proses pembentukan benih pada kubis bunga (a) curd pada kubis bunga mulai tidak beraturan dan membentuk cabang, (b) cabang membentuk kuncup bunga, (c) bunga terbentuk dari setiap kuncup bunga, (d) putik memanjang setelah mengalami fertilisasi dan terjadi pengisian benih, (e) pengisian benih pada kapsul benih yang terbentuk, (f) kapsul benih kering dan siap panen. berturut-turut sebesar 40.00 HST, 50.00 HST, 9.33 HST, dan 124.67 HST. Hal ini menjelaskan bahwa BOB 013 membutuhkan waktu yang lebih lama untuk menghasilkan benih dibandingkan genotipe lainnya, sebaliknya, BOB 001 dan BOB 002 nyata lebih rendah berdasarkan karakter waktu membentuk curd, waktu curd kompak, waktu berbunga, dan waktu panen benih. Hal ini menunjukkan bahwa BOB 001 dan BOB 002 membutuhkan waktu yang relatif lebih cepat untuk menghasilkan benih dibandingkan genotipe lainnya. Amasino et al. (2010) menyatakan bahwa waktu berbunga memiliki regulasi yang rumit dan diperlukan banyak gen yang berperan yang terintegrasi secara endogen dan eksogen (vernalisasi dan fotoperiode).

Lima genotipe kubis bunga yang yang diuji tergolong dalam genotipe yang memiliki waktu membentuk curd cepat atau memiliki fase vegetatif yang pendek $(\leq 40.00$ HST). Tanaman yang menghasilkan benih cepat, memiliki waktu membentuk curd yang cepat maka memiliki masa yang pendek atau dapat terhindar (escape) dari berbagai cekaman lingkungan. Semakin lama proses pembenihan, maka resiko kegagalan menghasilkan benih semakin tinggi akibat berbagai cekaman. Berdasarkan hasil penelitian ini, menunjukkan bahwa kubis bunga memerlukan waktu sekitar 76-85 hari dari tanaman mulai membentuk curd sampai panen benih dan memerlukan waku sekitar 29-49 hari dari tanaman membentuk curd sampai membentuk bunga.

Karakter kuantitatif yang terdiri atas diameter curd, jumlah benih per curd, jumlah benih per kapsul, dan bobot 1,000 benih terdapat pada Tabel 2. Diameter curd terbesar dimiliki oleh BOB 013 dan BOB 014 sebesar $13.98 \mathrm{~cm}$ dan $13.07 \mathrm{~cm}$, yang tidak berbeda nyata dengan BOB 001 sebesar $11.69 \mathrm{~cm}$. Diameter curd terkecil dimiliki BOB 003 sebesar $9.33 \mathrm{~cm}$. Diameter curd yang kecil memiliki waktu untuk menghasilkan benih lebih cepat dibandingkan genotipe yang memiliki diameter curd besar. Semakin kecil diameter curd maka keberhasilan pembentukan benih semakin tinggi. Curd yang besar membutuhkan waktu yang lama dalam tahap pemanjangan cabang bunga hingga panen benih.

Jumlah benih per curd, jumlah benih per kapsul, dan bobot 1,000 benih tidak berpengaruh nyata pada taraf $5 \%$. Jumlah benih per curd tertinggi dimiliki BOB 002 sebanyak 629.00 benih, diikuti oleh BOB 014 sebanyak 519.01 benih. Jumlah benih per curd terendah dimiliki BOB 001 sebanyak 173.25 benih. Jumlah benih yang dihasilkan per curd yang tinggi menunjukkan tingginya tanaman menghasilkan kapsul dan benih, serta minimnya kehilangan hasil. Rendahnya jumlah benih per curd umumnya disebabkan sedikitnya kapsul benih yang terbentuk, sedikitnya benih yang dihasilkan, dan faktor eksogen (kapsul benih mengalami busuk basah) dan endogen (tidak terjadi pengisian benih). Jumlah benih per kapsul pada kubis bunga yang dihasilkan memiliki kisaran 8.00-9.7 benih per kapsul. Jumlah benih per kapsul tertinggi dimiliki oleh BOB 014 sebanyak 9.87 benih dan jumlah benih per kapsul terendah dimiliki oleh BOB 003 sebanyak 6.97 benih. Bobot 1,000 benih tertinggi dimiliki oleh BOB 002 sebesar $2.29 \mathrm{~g}$ dan bobot terendah dimiliki oleh BOB 013 sebesar $1.82 \mathrm{~g}$. 


\section{Pengujian Daya Berkecambah}

Karakter pengujian benih yang diamati adalah daya berkecambah saat $5 \mathrm{MSP}$, dan daya berkecambah saat 10 MSP yang tersedia pada Tabel 3. Daya berkecambah saat 5 HSP dan 10 HSP menunjukkan bahwa genotipe BOB 001, BOB 002, dan BOB 003 memiliki daya berkecambah tertinggi, yaitu berturut-turut sebesar 94.67\%, 97.33\%, dan $93.33 \%$ (5 HSP) serta 96.00\%, 98.67\%, dan 97.33\% (10 HSP). Daya berkecambah pada 5 HSP dan 10 HSP terendah dimiliki BOB 014 sebesar 54.67\%. Keragaan daya berkecambah dapat dilihat pada Gambar 2.

Rahayu dan Suharsi (2015) menyatakan bahwa standar daya berkecambah yang tergolong tinggi untuk hampir seluruh benih adalah $\geq 80 \%$. Tingginya daya berkecambah, yaitu pada genotipe BOB 001, BOB 002, BOB 003, dan BOB 013 menunjukkan bahwa benih memiliki vabilitas yang tinggi. Pada pengamatan ini benih baru diuji setelah mengalami masa penyimpanan \pm 12 bulan dalam kulkas (1-4 ${ }^{\circ} \mathrm{C}$ ). Sadjad (2008) menyatakan bahwa periode simpan akan berpengaruh terhadap viabilitas benih, dimana penurunan viabilitas seiring dengan pertambahan waktu. Pada penelitian Rahayu dan Widajati (2007) tidak menurunnya viabilitas benih caisin pada periode 15 minggu disebabkan oleh benih-benih mengalami masa after ripening atau dormansi.Menurut Bewley dan Black (1984) kondisi suhu rendah menyebabkan kulit benih bertambah keras sehingga sifat dormansinya bertambah besar. Hal ini menyebabkan penyimpanan benih pada suhu di sekitar titik beku dapat memperpanjang dormansi benih menjadi lebih lama.

\section{Korelasi Antar karakter Pembenihan}

Korelasi merupakan derajat keeratan hubungan satu karakter dengan karakter lainnya (Safuan et al., 2014). Korelasi positif mengartikan bahwa peningkatan karakter tersebut dapat meningkatkan karakter lainnya, sebaliknya korelasi negatif mengartikan bahwa penurunan karakter tersebut meningkatkan karakter lainnya.Korelasi antarkarakter kuantitatif pembenihan kubis bunga ditunjukkan pada Tabel 4. Karakter yang memiliki korelasi positif sangat nyata tertinggi pada taraf $5 \%$ dengan koefisien korelasi sebesar 0.99; diantaranya waktu berbunga dengan waktu membentuk curd, waktu panen benih dengan waktu curd kompak, dan daya berkecambah saat 5 MSP dengan daya berkecambah saat $10 \mathrm{MSP}$, sedangan karakter yang memiliki korelasi negatif sangat nyata tertinggi dengan koefisien korelasi -0.98 adalah bobot 1,000 benih dengan waktu membentuk curd. Waktu berbunga memiiki korelasi positif dengan waktu membentuk curd, waktu curd kompak, waktu waktu panen benih, dan korelasi negatif dengan bobot 1,000 benih. Waktu berbunga yang cepat (nilai rendah)

Tabel 1. Rata-rata waktu membentuk curd, waktu curd kompak, waktu berbunga, dan waktu panen pada kubis bunga

\begin{tabular}{ccccc}
\hline Genotipe & Waktu membentuk curd (HST) & Waktu curd kompak (HST) & Waktu berbunga (HST) Waktu panen benih (HST) \\
\hline BOB 001 & $33.00 \mathrm{c}$ & $43.00 \mathrm{c}$ & $62.33 \mathrm{c}$ & $108.67 \mathrm{c}$ \\
BOB 002 & $33.00 \mathrm{c}$ & $43.00 \mathrm{c}$ & $63.00 \mathrm{c}$ & $111.00 \mathrm{c}$ \\
BOB 003 & $33.00 \mathrm{c}$ & $45.67 \mathrm{~b}$ & $67.00 \mathrm{c}$ & $116.00 \mathrm{bc}$ \\
BOB 013 & $40.00 \mathrm{a}$ & $50.00 \mathrm{a}$ & $89.33 \mathrm{a}$ & $124.67 \mathrm{a}$ \\
BOB 014 & $37.33 \mathrm{~b}$ & $50.00 \mathrm{a}$ & $78.90 \mathrm{~b}$ & $122.81 \mathrm{ab}$ \\
\hline KK $(\%)$ & 0.73 & 0.56 & 6.13 & 3.41 \\
\hline
\end{tabular}

Keterangan : Angka-angka pada kolom yang sama yang diikuti oleh huruf yang sama tidak berbeda nyata pada uji DMRT taraf 5\%, $\mathrm{KK}=$ koefisien keragaman.

Tabel 2. Rata-rata yaitu diameter curd, jumlah benih per curd, dan jumlah benih per kapsul pada kubis bunga

\begin{tabular}{ccccc}
\hline Genotipe & Diameter curd $(\mathrm{cm})$ & Jumlah benih per curd $^{*}$ & Jumlah benih per kapsul & Bobot 1,000 benih $(\mathrm{g})$ \\
\hline BOB 001 & $11.69 \mathrm{ab}$ & 173.25 & 8.00 & 2.17 \\
BOB 002 & $10.38 \mathrm{bc}$ & 629.00 & 8.98 & 2.29 \\
BOB 003 & $9.33 \mathrm{c}$ & 293.00 & 6.97 & 2.26 \\
BOB 013 & $13.98 \mathrm{a}$ & 183.44 & 9.01 & 1.82 \\
BOB 014 & $13.07 \mathrm{a}$ & 519.01 & 9.87 & 1.96 \\
\hline KK $(\%)$ & 10.10 & 12.95 & 12.27 & 24.43 \\
\hline
\end{tabular}

Keterangan : Angka-angka pada kolom yang sama yang diikuti oleh huruf yang sama tidak berbeda nyata pada uji DMRT taraf 5\%; $\mathrm{KK}=$ koefisien keragaman; *transformasi data dengan $\log (x)$. 
dapat dilihat dari cepatnya waktu membentuk curd, waktu curd kompak, waktu waktu panen benih, dan meningkatnya bobot 1,000 benih. Tingginya daya berkecambah tidak berpengaruh terhadap komponen pembenihan lainnya.

Tabel 3. Rata-rata daya berkecambah saat $5 \mathrm{MSP}$, dan daya berkecambah saat 10 MSP pada kubis bunga

\begin{tabular}{lcc}
\hline \multicolumn{1}{c}{ Genotipe } & DB (5 HSP) & DB (10 HSP) \\
\hline BOB 001 & $94.67 \mathrm{a}$ & $96.00 \mathrm{a}$ \\
BOB 002 & $97.33 \mathrm{a}$ & $98.67 \mathrm{a}$ \\
BOB 003 & $93.33 \mathrm{a}$ & $97.33 \mathrm{a}$ \\
BOB 013 & $77.33 \mathrm{~b}$ & $82.67 \mathrm{~b}$ \\
BOB 014 & $54.67 \mathrm{c}$ & $54.67 \mathrm{c}$ \\
\hline KK $(\%)$ & 6.25 & 4.58 \\
\hline
\end{tabular}

Keterangan : Angka-angka pada kolom yang sama yang diikuti oleh huruf yang sama tidak berbeda nyata pada uji DMRT taraf 5\%, KK = koefisien keragaman, $\mathrm{DB}=$ daya berkecambah, $\mathrm{HSP}=$ hari setelah perlakuan.
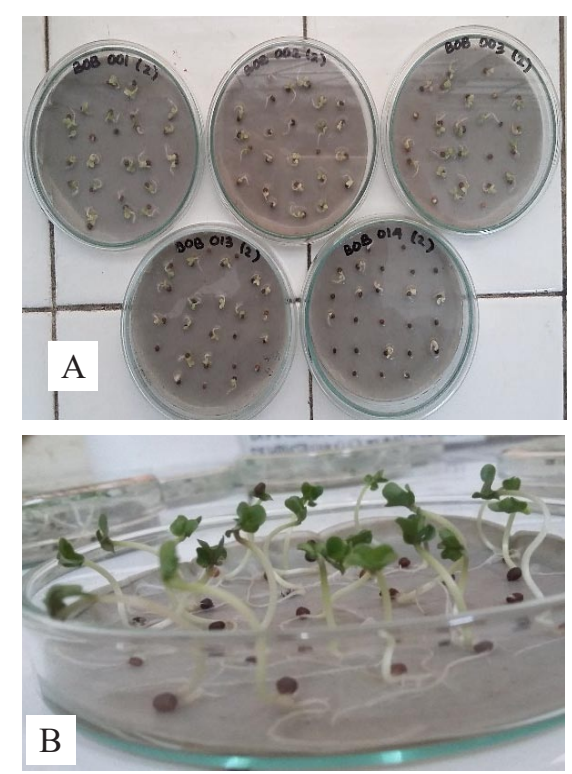

Gambar 2. Pengujian daya berkecambah benih kubis bunga saat 2 HSP (A) dan 5 HSP (B)

Tabel 4. Analisis korelasi antar karakter pembenihan pada kubis bunga

\begin{tabular}{|c|c|c|c|c|c|c|c|c|c|}
\hline & WMC & WCK & WBB & WPB & DC & B1000 & JBK & $\mathrm{JBC}$ & DB5 \\
\hline WCK & $0.91^{*}$ & & & & & & & & \\
\hline WBB & $0.99^{* *}$ & $0.94^{*}$ & & & & & & & \\
\hline WPB & $0.91^{*}$ & $0.99^{* *}$ & $0.95^{*}$ & & & & & & \\
\hline $\mathrm{DC}$ & $0.89^{*}$ & $0.73^{\text {tn }}$ & $0.82^{\text {th }}$ & $0.67^{\text {th }}$ & & & & & \\
\hline B1000 & $-0.98^{* *}$ & $-0.88^{*}$ & $-0.95^{*}$ & $-0.85^{\text {tn }}$ & $-0.95^{*}$ & & & & \\
\hline JBK & $0.61^{\text {tn }}$ & $0.51^{\text {tn }}$ & $0.51^{\text {tn }}$ & $0.47^{\text {th }}$ & $0.72^{\text {tn }}$ & $-0.58^{\text {tn }}$ & & & \\
\hline JBC & $-0.20^{\operatorname{tn}}$ & $-0.10^{\text {tn }}$ & $-0.23^{\mathrm{tn}}$ & $-0.07^{\mathrm{tn}}$ & $-0.24^{\text {tn }}$ & $0.33^{\text {th }}$ & $0.50^{\text {th }}$ & & \\
\hline DB5 & $-0.72^{\mathrm{tn}}$ & $-0.87^{\mathrm{tn}}$ & $-0.70^{\operatorname{tn}}$ & $-0.79^{\text {tn }}$ & $-0.70^{\operatorname{tn}}$ & $0.74^{\text {th }}$ & $-0.71^{\text {tn }}$ & $-0.17^{\text {tn }}$ & \\
\hline DB10 & $-0.65^{\mathrm{tn}}$ & $-0.80^{\operatorname{tn}}$ & $-0.62^{\mathrm{tn}}$ & $-0.72^{\text {tn }}$ & $-0.67^{\mathrm{tn}}$ & $0.68^{\text {tn }}$ & $-0.74^{\mathrm{tn}}$ & $-0.24^{\mathrm{tn}}$ & $0.99^{* *}$ \\
\hline
\end{tabular}

Keterangan: "berkorelasi nyata; ${ }^{* *}$ berkolasi sangat nyata;tidak berkorelasi nyata pada taraf 5\% berdasarkan metode Pearson, $\mathrm{WMC}=$ waktu membentuk curd (HST), WCK = waktu curd kompak (HST), WBB = waktu berbunga $(\mathrm{HST}), \mathrm{WPB}=$ waktu panen benih $(\mathrm{HST}), \mathrm{DC}=$ diameter $\operatorname{curd}(\mathrm{cm}), \mathrm{B} 1000=$ bobot 1,000 benih, JBK $=$ jumlah benih per kapsul, JBC $=$ jumlah benih per curd, DB5 = daya berkecambah 5 MSP, DB10 = daya berkecambah 10 MSP.

\section{KESIMPULAN}

Pembenihan hanya dihasilkan pada tanaman yang ditanam di dataran tinggi. Daya berkecambah diatas $80 \%$ dimiliki genotipe $\mathrm{BOB} 001$, BOB 002, BOB 003, dan BOB 013. Genotipe BOB 001, BOB 002, BOB 003, BOB 013, dan BOB 014 mampu menghasikan benih pada suhu kisaran 21.00-23.50 ${ }^{\circ} \mathrm{C}$ dan pada suhu kisaran $26{ }^{\circ} \mathrm{C}$ tanaman sudah tidak dapat berbunga dan menghasilkan benih. Waktu berbunga yang cepat dapat dilihat dari cepatnya waktu membentuk curd, waktu curd kompak, waktu waktu panen benih, dan meningkatnya bobot 1,000 benih.

\section{UCAPAN TERIMA KASIH}

Terima kasih disampaikan kepada Bapak Juhana (Kebun Percobaan Pasir Sarongge, Cianjur), Bapak Ahmad Kurniawan (Kebun Percobaan PKHT IPB Tajur II, Bogor), dan seluruh teknisi atas bantuannya dalam pelaksanaan percobaan. Penelitian ini dibiayai dari Hibah Penelitian JATAFF. 


\section{DAFTAR PUSTAKA}

Amasino, R. 2010. Seasonal and developmental timing of flowering. The. Plant. J. 61(6):1001-1013.

Arias, T., M.A. Beilstein, M. Tang, M.R. McKain, J.C. Piries. 2014. Diversification times among Brassica (Brassicaceae) crops suggest hybrid formation after 20 million years of divergence. American. J. Botany. 101(1):86-91.

Bewley, J.D., M. Black. 1984. Seed Physiology of Development and Germination. Plenum Press, New York.

[BMKG] Badan Meteorologi Klimatologi dan Geofisika. 2017. Data Iklim Stasiun Pasir Sarongge dan Tajur. BMKG, Bogor.

Driedonks, N., I.Rieu, W.H.Vriezen. 2016. Breeding for plant heat tolerance at vegetative and reproductive stages. Plant. Reprod. 29(1):67-79.

Gomies, L., H. Rehatta, J. Nandissa. 2012. Pengaruh pupuk organic cair R11 terhadap pertumbuhan dan produksi tanaman kubis bunga (Brassica oleracea var. botryris L.). Agrologia. 1(1):13-20.

Gray, A.R. 1982. Taxonomy and evolution of broccoli (Brassica oleracea var. italica). Econ. Bot. 36:397410.

Guo, D.P., G.A. Shah, G.W. Zeng, S.J. Zheng. 2004. The interaction of plant growth regulators and vernalization on the growth and flowering of cauliflower (Brassica oleracea var. botrytis). Plant. Growth. Reg. 43:163-171.

Hasan, Y., W. Briggs, C. Matschegewski, F. Ordon, H. Stiitzel, H. Zetzsche, S. Groen, R. Uptmoor. 2016. Quantitative trait loci controlling leaf appearance and curd initiation of cauliflower in relation to temperature. Theor. Appl. Genet. 129(7):1273-1288.
Hossain, M.F., N.Ara, M.R.Uddin, S. Dey, M.R. Islam. 2011. Effect of time of sowing and plant spacing on broccoli production. Trop. Agri. Res \& Exten. 14(4):90-92.

Kim, T.K. 2014. Brassica oleracea (Botrytis Group). Di dalam: Kim TK, editor. Edible Medicinal and Non-Medicinal Plants. Vol 7, Flowers. Springer Science+Business Media Dordrecht, New York.

Matschegewski, C., H. Zetzche, Y. Hasan, L. Leibeguth, W. Briggs, F. Ordon, R. Uptmoor. 2015. Genetic variation of temperature-regulated curd induction in cauliflower: elucidation of floral transition by genome-wide association mapping and gene expression analysis. Frontiers. Plant. Sci. 720(6):114.

Rahayu, A.D., T.K. Suharsi. 2015. Pengamatan uj daya berkecambah dan optimlisasi substrat perkecambahan benih kecipir [Psophocarpus tetragonolobus L. (DC)]. Bul. Agrohort. 3(1): 18-27.

Rahayu, E., E. Widajati. 2007. Pengaruh kemasan, kondisi ruang simpan dan periode simpan terhadap viabilitas benih caisin (Brassica chinensis L.). Bul. Agron. 35(3)191-196.

Rihan, H.Z., M. Al-Issawi, M.P. Fuller. 2017. An analysis of the development of cauliflower seed as a model to improve the molecular mechanism of abiotic stress tolerance in cauliflower artificial seeds. Plant. Physiol. Biochem. 116:91-105.

Sadjad, S. 2008. The Phylosophy of Seed. IPB Pr, Bogor.

Safuan, L.O., D. Boer,. Wijayanto, N. Susanti. 2014. Analisis koefisien lintas berbagai sifat agronomi yang mempengaruhi hasil kltivar jagung pulut (Zea mays Ceritina Kulesh) lokasi Sulawesi Tenggara. Agriplus. 24(2):136-143. 